\title{
日本における八景の分布について
}

\section{Distribution of Eight Scenery in Japan}

\author{
田中誠雄 ${ }^{*}$ 金東必 ${ }^{* *}$ 青木陽二*** \\ Masao TANAKA Dong-Pil KIM Yoji AOKI
}

摘要 : 中国に始まった山水画の一つに宋の時代に描かれた潇湘八景画がある。これは我が国に伝わり， 日本人の風影観に大きな影響を与えた。室町時代に絵画として伝わって以来, 近江八景など多くの八 景を日本の地形に見いだすことになった。日本の地に見いだされた現在に至るまでの八景の分布を明 かにすることにより，風景観としての八景の影響を明かにするものである。この資料では現在までに 地方自治体により把握されている八景の分布と見いだされた年代を紹介するものである。回答の得ら れない自治体があるので，今後の調査により八景の数は增加すると思われるが, 現在までの資料でも 八景の影響の大きさを推定するに十分な価値を有する。

\section{1.はじめに}

日本人の風景観に大きく影響し，多くの画 家の画題となった八景は中国に原点を求めら れる。これは風景評価の様式が中国で生まれ (鈴木 1981)，文字や技術と同じょうに古代中 国から伝えられたことを表わす。そして八景 は朝鮮, 台湾, 日本へと広く伝わった風景評 価の様式である（田中 1989-98）。風景は実体 験から得られたものであるので, 八景は当時 の日本人には到達が困難な場所における体験 であった。よって, 絵画という一つの抽象的 な概念を伝える方法により伝わった。そのた め絵画から連想される空間を身近な場所に求 め，その概念の具現化を試みたのであった。 場所の違いは次第に風景評価の内容までも変 えて, 新しい風景評価の要素を見いだした。

本調查では，日本全国に分布する八景の所 在を知ることにより，八景の伝播とその概念 の変容, 及び風景評価の広がりについて明か にするものである。

\section{2. 調查の方法}

各都道府県の教育委員会を中心とした担当 者に刘し，1996 年 6 月にアンヶート票を送 り，八景の所在と特性について 8 月までに回 答を得た。その後回答をとりまとめ, 1998 年 の 12 月までに回答の内容を確かめた。調査 の内容は, 分布する範用, 該当する市町村, 八景の個別名称, 観賞された時代, 絵画の記 録の有無, 写真の記録の有無, 文書としての 記述の有無である。また調査票を記入した担 当者名も記載させた。これは後日の調査内容 の確認の為である。

\section{3. 全国の分布}

表1のように, 北海道から沖縄まで広く八 景呼ばれる風景が分布することがわかった。
多い県では 51 箇所, 少ない県ではなしとい うところもあった。市町村まで調查しないと， よりローカルなものは見つからないかも知れ ないが, 全国に地域によってこのような風景 評価が広まったところと，そうでないところ があると思われる。これは八景としての風景 評価が得られない気候・地形条件の場所であっ たのか, 文化として伝わらなかったのか，現 在までの知見では詳しくは分からない。北海 道まで分布しているので, 昭和 40 年代まで には景を選定するということが一応全国に伍 わったと考えられる。回答された八景には中 国で選ばれた，㴋湘八景を踏襲したもの（八 景型）と一部が異なったものや追加されたも の (変形型)，かなり潚湘八景之は異なって その地方の名所を中心に約 $6-12$ 景を選ん だもの (名所型) の 3 種類が見られる。そし て時代が新しくなるに従って八景型が少なく なる。これは韓国に伝わった潚湘八景の報告 とも一致している (Kang and Kim 1991)。 地域的に見ると, 中国で生まれた澑湘八景の パターンを踏襲しているのは青森県から宮崎 県までであった。

また一般の人々に知られた有名な八景は自 治体の回答によれば水戸八景が東の端に当た る。このことは水戸以北には，八景型の風景 評価の広まりに何らかの遅れ，もしくは不都 合があったのではないかと考えられる。水戸 八景は沬戸の後期に盛んになったが，そのこ ろには青森や盛岡でも一応八景が定められて いるので, 文化の伝播として本州北部までは 伝わったと考えられる。

\section{4. 各自治体別の分布}

北海道では厚岸町之室蘭市にあることが知 られている。2 箇所とも近年設定されたもの で名所型である。本格的に開拓が始まったの
が明治以降であり，風景評価に関心が起こっ たのも富良野や美瑛などのように近年である ので理解できる。

青森県は弘前市, 八户市, 平内町, 蟹田町, 深浦町, 平賀町, 小泊村, 川内町に分布して いる。滭湘八景型は 4 筒所, 名所型が 6 筒所 である。小泊を除いて，いずれも明治以降の 指定である。岩手県は盛岡市に有り, 南部藩 が江戸中期に指定している。絵画の資料も残つ ているので, 視対象を特定しやすい。これは 潚湘八景を踏襲している。宮城県は八景の記 録がないと報告している。秋田県では角館町 に 1 箇所, 山形県では酒田市, 山形市に 2 箇 所見られる。これらはいずれも名所型である。 福島県では会津若松市, 猪苗代町, いわき市, 相馬市に見られ, 八景型が 2 箇所, 変形型が 3 筒所, 名所型が 1 箇所ある。

茨城県では県内広く分布し, 51 箇所が報 告された。八景型が 24 筒所, 変形型が 12 筒 所, 名所型が 15 箇所である。栃木県では日 光に 1 箇所見られる。群馬県では県内広く分 布し，42 筒所の報告があった。八景型は 5 筒所, 变形型が 17 筒所あった。埼玉県では 熊谷市，幸于市，越谷市と県西に見られ，八 景型が 2 筒所, 変形型が 1 箇所, 名所型が 2 筒所見られた。千葉県では印箅村, 市川市, 袖ヶ浦市, 木更津市, 東金市, 一宮町, 市原 市に見られた。八景型は 3 筒所, 名所型が 4 簓所見られた。東京都は回答が得られなかっ た。神余川県では横浜市, 横須賀市, 平塚市, 藤沢市, 逗子市, 二浦市に見られ，八景型が 10 簓所, 変形型が 2 箇所, 名所型が 3 箇所 見られた。

新潟県からは回答が得られなかった。富山 県からはないとの回答があった。石川県から は全域に広く見られ，八景型が 14 筒所，変 形が 4 箇所, 名所型が 16 箇所見られた。福

・神戸市建設局 “韓国密陽産業大学校造景学科 ‥国立環境研究所社会環境システム部 
井県では敦賀市, 勝山市に見られ，八景型は 2 箇所と名所型 1 箇所見られた。山梨県では 塩山市，山梨市，大月市など見られ，变形型 が 1 箇所と名所型が 6 箇所見られた。長野県 では木曽谷に変形型が 1 箇所見られた。岐阜 県では県全体に変形型が 1 筒所見られた。静 岡県では県中部に八景型が 1 箇所見られた。

愛知県ではないとの報告があった。

三重県ではないとの報告があった。滋賀県 では近江八景が浾湘八景型として報告された。 また名所型が 2 箇所報告された。京都府では ないとの報告があった。大阪府では大阪市， 堺市，大阪狭山市に分布することがわかった。 兵庫県では県内に広く分布し，八景型が 4 筒 所, 変形型が 6 箇所, 名所型が 20 箇所見ら れた。奈良県では名所型が 1 箇所報告された。 和歌山県からはないとの報告があった。

鳥取県では鳥取市, 米子市に, 八景型が 1 筒所, 変形が 2 筒所見られた。島根県ではな いとの報告があった。岡山県からは回答が得 られなかった。広島県では広島市と宮島町に 3 箇所あるが，いずれも八景型がくずれた名 所型であった。山口県では下関市, 山儿市, 萩市, 長門市にみられ, 八景型が 1 簓所, 名 所型が 5 筒所見られた。

徳島県と香川県にはないと報告があった。 愛媛県では県内に広く分布し，八景型が 5 箇 所, 変形型が 2 筒所, 名所型が 16 筒所見ら れた。高知県には一筒所見られる。

福岡県では北九州市と添田町にあることが わかった。佐賀県には二瀬村に一箇所あるこ とがわかった。長崎県では佐世保市周辺に名 所型が 1 筒所あることがわかった。熊本県で は熊本市, 八代市, 菜池市, 三角町, 松橋町, 長陽村, 芦北町に分布することがわかった。 八景型が 3 箇所, 名所型が 10 筒所見られた。 大分県では別府市に名所形が 1 箇所あること がわかった。宮崎県では串間市, 高千穂町に あることがわかった。八景型が 1 箇所, 変形 型が 1 簓所, 名所型が 3 筒所見られた。鹿児 島県では大島支庁に 1 筒所, 名所型があるこ とがわかった。

沖縄県では那覇市に 4 筒所の名所型がある ことがわかった。

\section{5. 時代別分布}

現在までに集まった回答より，八景の設定 を時代别に集計すると, 表 2 のようになる。 設定が始まった室町時代には, 3 筒所, 安土 桃山時代は, 1 簓所, 江戸時代は 71 箇所で ·番多く，広まったことを示している。明治 時代には 25 筒所, 大正時代には 5 筒所, 昭 和には 21 箇所, 平成に入っても 7 筒所と, 末だに風景評価の一つの型を示している。

時代の長さから判断すると, 汇戸時代より 明治時代の方が多い。これは八景の広がりが

\section{表-1 八景の全国分布（1999 年 1 月 23 日現在）}

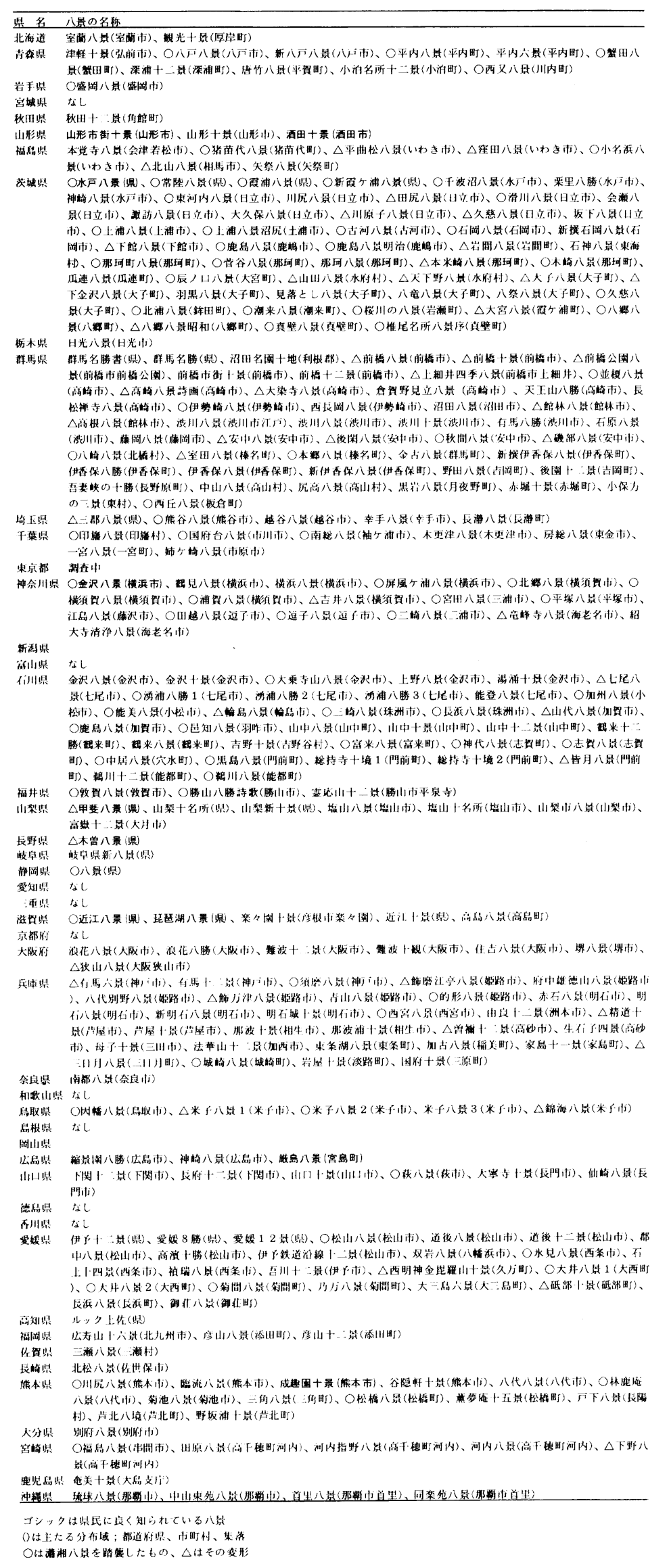


表 -2 設定時代の区分

\begin{tabular}{|c|c|c|c|c|c|c|c|}
\hline 時代 & 期間 (年) & 設定釉数 & 初期 & 中期 & 後期 & 不明 & 頻度 (䉪所 $/$ 年) \\
\hline 室町 & 234 & 3 & 1 & 1 & 1 & 0 & 0.01 \\
\hline 安土辀山 & 25 & 1 & 1 & 0 & 0 & 0 & 0.04 \\
\hline 江戸時代 & 265 & 71 & 9 & 17 & 32 (5) & 13 & 0.27 \\
\hline 明治 & 45 & 25 & 3 & 4 & $12(3)$ & 2 & 0.55 \\
\hline 大正 & 15 & 5 & 3 & 0 & $1(1)$ & 1 & 0.33 \\
\hline 昭和 & 64 & 21 & 11 & 4 & 0 & 0 & 0. 33 \\
\hline 平成 & 10 & 7 & 7 & & & & 0.70 \\
\hline
\end{tabular}

江户後期から始まったからである。現在む評 価が続いているが, 古い八景が失われて, 新 しいものが選ばれている場合と，全く別に定 められたものがある。これらの変遷を分析す ることにより, 風景観の変遷も分かると思わ れる。

\section{6. 考察}

この度の調査で現在までに全国に 284 筒所 の八景的風景群が見つかった。潇湘八景を踏 襲するものは 85 箇所, 变形されたものが 47 箇所見つかった。これらの結果はまだ報告が ない都県からの回答により，また市町村につ いて調査をすることによりさらに増加する可 能性がある。このことは風景評価という現象 が，日本人にとって広く行なわれた現象であ ることを示している。よって Appleton （1980）が風景評価を科学と結び付けようと したことは妥当なことと考えられる。

風景評価は, 人間の知的水準に影響される という指摘があるので（青木 1997），その社 会における文化の程度の一側面を表わすと考 えられる。また潇湘八景をそのまま踏襲する ことが容易でなかった自然条件，例えば沖縄 の積雪 (小林 1993）も考えられるので，八景
型の分布は, ひとつの見方がどこまで伝達し たかを教えてくれる。これにより，10 世紀 中国で確立された風景評価の様式が，日本全 国に数世紀かけて広まったことが分かり，日 本における中国文化の影響の大きさを改めて 知った。これは芳賀（1986）が八景絵画の影 響において指摘したことと同じである。 風景評価がこのように文化的色彩の強いも のである以上, 西洋文化の影響やまだ日本で は知られていない文化の影響により, 風景評 価は変化する可能性がある。一方, 日本にお ける八景の変容を見ると, 日本における自然 条件の影響の大きさが分かる。このような現 象を把握し, 人類に共通な風景評価や, 気候 風土による変容を知ることが，これからの風 景計画に求められるものと思われる。

\section{7.まとめ}

全国の都道府県の担当者に八景に関するア ンヶート調查を実施することにより, 以下の 点が明かになった。

1. 全国に 200 を越える評価された風景群が あることが分かった。中国に発生した潕湘八 景型は 85 箇所ほど見つかった。

2. 風景評価は日本全国で広く行なわれてい
る現象であることがわかった。

3. 潇湘八景型の分布には限界があることが 分かった。

4.八景が急速に広まった時代があった。

\section{謝辞}

全国調査のアイデイアは篠原修東京大学教

授にいただいた。謝して記す。

調查では全国の自治体担当者の快い協力を 得た。改めて謝意を表する。また茨城県の八 景調查では, 川崎建夫大成女子高校教諭の資 料を参考とした。御好意に感謝する。

\section{参考文献}

1）青木陽二（1997）：欧文文献に見る自然 風景における景観評価研究の变遷 : ラン ドスケープ研究 61(1),68-73

2 ) Appleton, J.(1980); Landscape in the Arts and the Science : University of Hull, Hull, 16pp.

3 ) 芳賀徽（1986）: 風景の比較文化史一 「潇湘八景」と「近江八景」: 比較文学研 究 50, 1-27

4) Kang, Young-Jo and Kim, YoungRan (1991): A Study on the Type and the Spatial Location of PalKyong(eight scenery) in KOREA : 韓国庭苑学会誌 10,27-36

5 ) 小林亨 (1993) : 移ろいの風景論, 鹿島出 版会, 東京, $211 \mathrm{pp}$.

6 ）鈴木敬（1981）: 中国絵画史(上), 吉川弘 文舘, 東京, $337 \mathrm{pp}$.

7 ）田中誠雄（1989-98）：近江八景小考：平 成元 -10 年度日本造園学会関西支部大 会研究発表要旨

Summary : The Eight Scenery is a typical Sansui (mountain and water landscape) painting, was painted in old China of Sung Dynasty, circa 10th century. The painting was introduced to Japan in 14th century and affected to the landscape appreciation of Japanese geographical condition until now. The questionnaire survey was held on to local administrations to investigate the distribution of the Scenery in Japan. The results are obtained as followings: 85 original type (Chinese type appreciation) Eight Sceneries, 284 Japanese type Sceneries, and 47 modified type Sceneries are found. Eight Sceneries were observed throughout Japan. However, northernmost distribution of Chinese type show the boundary within Honshu and none in Hokkaido. The appreciation has the popularity at the Edo Era (1603-1867). 